\title{
The effect of kidding season on productivity of indigenous Matebele goats of Zimbabwe
}

\author{
L. M. Sibanda ${ }^{1}$, M. J. Bryant ${ }^{2}$ and L. R. Ndlovu' ${ }^{1}$ \\ 'Department of Animal Science, University of Zimbabwe, PB MP167 Mount Pleasant, Zimbabrue \\ ${ }^{2}$ Department of Agriculture, University of Reading, Earley Gate, Reading RG6 2AT
}

\section{Introduction}

Goats play a very important rôle in the agriculture of Zimbabwe especially in the semi-arid parts where $70 \%$ of the current two million goat population is found. There are two indigenous types of goats; the small Mashona goat which resembles the Small East African type and the larger Matebele goat which resembles and may in fact be related to the Boer goat. Very little is known about the production and productivity of goats under traditional husbandry systems. The aim of the work reported here was to provide baseline data of the goat production system in Matebeleland, so as to enable the identification of constraints and introduction of specific interventions to improve productivity.

\section{Material and methods}

Site

The work was carried out in the Guyu communal lands of Zimbabwe, altitude $765 \mathrm{~m}$, coordinates $25^{\circ} 59^{\prime}$ longitude and $21^{\circ} 23^{\prime}$ latitude. The mean rainfall and minimum and maximum temperatures during the study period are shown in Table 1 below.

Table 1 Mian rainfall, maximum and minimum temperatures recorted in Guyu during the years 1989-1991

\begin{tabular}{lccc}
\hline & & \multicolumn{2}{c}{ Dry season } \\
\cline { 3 - 4 } & $\begin{array}{c}\text { Wet season } \\
\text { Cool } \\
\text { (Nov.-Apr.) }\end{array}$ & $\begin{array}{c}\text { Cold } \\
\text { (May-Aug.) }\end{array}$ & $\begin{array}{c}\text { Hot } \\
\text { (Sept.-Oct.) }\end{array}$ \\
\hline Minimum temperature ${ }^{\circ} \mathrm{C}$ & 18.7 & 9.4 & 14.7 \\
Maximum temperature ${ }^{\circ} \mathrm{C}$ & 31.0 & 26.0 & 30.0 \\
Annual rainfall (mm) & 330 & 2.6 & 9.2 \\
No. of rainy days & 40 & 3 & 3 \\
\hline \hline
\end{tabular}

\section{Data}

Seven flocks comprising a total of 679 goats were individually identified by means of eartags. The animals remained under the ownership and management of the individual farmers. As from May 1989 until June 1991 each flock was visited fortnightly, all goats were weighed, newborn kids were eartagged and weighed, and records pertaining to births, deaths, and any goats removed or brought into the flock were obtained from the farmer. Analysis of variance was carried out for litter size and survival, 150-day weight, doe post-partum weight, subsequent parturition interval and annual productivity based on the index: (weight of weaned progeny $\times 365$ )/parturition interval. The effect of kidding season on the above variables was tested.

\section{Results}

During the 2 years, 685 kids were born, $68 \%$ of which were born during the cold dry season (June to August). Two hundred kids died before weaning, the highest number of deaths ( $65 \%$ of all deaths) occurring during the cold dry season. The season of parturition had a significant effect on all the variables. Does kidding in the wet season (November to April) were proportionately heavier by up to 0.4 and weaned kids that were almost double the weight of kids born during the dry season (Table 2). The subsequent kidding interval was 84 days shorter for does kidding in the wet season than in the dry season. The annual productivity index of does kidding in the wet season was, on average, $14 \mathrm{~kg}$ more than for does kidding in the dry season.

Table 2 Overall productivity means and monis for the parturitions during the uet and dry seasols

\begin{tabular}{|c|c|c|c|c|c|}
\hline & \multicolumn{5}{|c|}{ I.east-square means } \\
\hline & \multicolumn{2}{|c|}{ Overall } & \multicolumn{2}{|c|}{ Wet scason } & Dry season \\
\hline & Mean & s.e. & Mean & s.e. & Mean s.c. \\
\hline $\begin{array}{l}\text { Weaning } \\
\text { weight (kg) }\end{array}$ & 9.7 & (0)15 & $13 \cdot 2$ & 0.65 & $\begin{array}{ll}7.0 & 0.95\end{array}$ \\
\hline $\begin{array}{l}\text { Doe post-kidding } \\
\text { weight (kg) }\end{array}$ & $35 \cdot 1$ & 0.46 & $43 \cdot 7$ & 0.95 & $31.4 \quad 2.01$ \\
\hline $\begin{array}{l}\text { Subsequent kidding } \\
\text { interval (days) }\end{array}$ & 294 & 5.79 & 243 & 8.45 & $327 \quad 15 \cdot 31$ \\
\hline Productivity (kg) & $12 \cdot 5$ & 0.37 & $21 \cdot 6$ & 0.75 & $\begin{array}{lll}6.2 & 0.84\end{array}$ \\
\hline
\end{tabular}




\section{Discussion}

In traditional systems where breeding is not controlled, season of parturition is one of the most important parameters influencing productivity. African indigenous livestock are often said to be of low productivity because most of the available research results are from single-round surveys which ignore the seasonal variation in productivity. Matebele goats kidding in the best season were $12 \mathrm{~kg}$ heavier than does kidding in the dry season and weaned kids that were $6 \mathrm{~kg}$ heavier. The productivity index used takes into consideration prolificacy, kid survival to weaning, weight of weaned progeny per year and kidding intervals and is very useful in quantifying and comparing productivity between flocks and different systems. The $6 \mathrm{~kg}$ productivity index for does kidding in the dry season is inferior to reported productivity indices for Keyna, Sudan and Mali of $12.4,25.9$ and $18.7 \mathrm{~kg}$ respectively (Wilson, 1984). However, the $21.6 \mathrm{~kg}$ yield in the wet season is close to the high yields reported for the Sudan.

The dry season (June to October) has a deleterious effect on all the reported productivity traits. Given the fact that grazing lands are communally owned, breeding cannot be easily controlled. Supplementary feeding of does kidding during the dry season could improve the condition of the does during lactation which could increase milk yield leading to optimal kid survival rates and weaning weights.

\section{Conclusion}

The potential productivity of the Matebele goat is high. The wide variation in productivity between the different months reflects a large amount of untapped potential. Supplementary feeding of does and kids during the dry months is recommended so as to narrow the gap in productivity between the best and worst months of parturition.

\section{Acknowledgements '}

Funding for this work was provided jointly by the University of Zimbabwe Research Board and the International Development Research Center, Canada.

\section{Reference}

Wilson, R. T. 1984. Indigenous goats: productivity in traditional livestock systems of semi-arid Africa. International Goat and Sheep Research 2(3): 243-251. 